\title{
Persepsi Dukungan Organisasi, Rasa Berdaya Psikologis, dan Pengaruhnya Terhadap Keterikatan Karyawan Pertelevisian
}

\author{
Nina Muzdalifah, Wustari L Mangundjaya \\ nina.muzdalifah@gmail.com
}

Fakultas Psikologi, Universitas Indonesia, Depok, Indonesia

\begin{abstract}
Employee engagement (EE) has an impact on organizational performance and employees regarding emotional and health conditions. There are EE supporting factors from companies or jobs and employees as individuals. The purpose of this study is to determine the effect of perceived organizational support (POS) on employee engagement (EE) mediated by psychological empowerment (PE). The data was collected using POS questionnaire adapted from Eisenberger (1986), PE questionnaire adapted from Speitzer (1995), and EE questionnaire adapted from Hewitt (2015). Partisipants are 116 people consisted of staff, supervisors, and managers who worked in several television industries in Jakarta Indonesia whose are permanent employees with work period of 2 years. The results showed that there is a direct effect from POS to EE and the indirect effect of POS to EE through PE as mediator. Increasing POS and EE will further increase EE. In conclusion, $P E$ has a role as a positive partial mediation between POS and EE.
\end{abstract}

Keywords: perceived organizational support; psychological empowerment; employee engagement

Keterikatan karyawan (employee engagement/EE) memiliki dampak pada kinerja organisasi dan juga pada karyawan dalam hal kondisi emosi dan kesehatan yang baik. Terdapat faktor pendukung dari EE, baik yang berasal dari perusahaan atau pekerjaan dan juga dari karyawan sebagai individu. Tujuan penelitian ini adalah ingin mengetahui pengaruh persepsi dukungan organisasi (perceived organizational support/POS) pada keterikatan karyawan (employee engagement/EE) yang dimediasi oleh rasa berdaya psikologis (psychological empowerment/PE). Pengumpulan data dilakukan dengan menggunakan kuesioner adaptasi alat ukur POS dari Eisenberger (1986), rasa berdaya psikologis dari Speitzer (1995), dan keterikatan karyawan dari Hewitt (2015). Partisipan berjumlah 116 orang yang terdiri atas level staf, supervisor, dan manajer yang bekerja di beberapa industri pertelevisian di Jakarta Indonesia yang merupakan karyawan tetap dan memiliki masa kerja 2 tahun. Hasil yang didapatkan adalah terdapat pengaruh langsung dari POS ke EE dan pengaruh tidak langsung POS ke EE melalui mediator PE yang signifikan. Peningkatan POS dan EE akan semakin meningkatkan EE karyawan. Dengan kata lain, PE memiliki peran sebagai mediasi parsial positif antara POS dengan EE.

Kata kunci: persepsi dukungan organisasi; rasa berdaya psikologis; keterikatan karyawan

Received: September 14, 2018 Accepted: June 21, 2019

How to cite: Muzdalifah, N., \& Mangundjaya, W. L. (2018). Persepsi Dukungan Organisasi, Rasa Berdaya Psikologis, dan Pengaruhnya Terhadap Keterikatan Karyawan Pertelevisian. MEDIAPSI, 5(1), 1-15. doi: https://doi.org/10.21776/ub.mps.2019.005.01.1

\section{Pendahuluan}

Industri pertelevisian merupakan bidang industri kreatif yang bergerak dalam hal hiburan dan juga penyampai informasi kepada masyarakat. Jenis industri kreatif memiliki karakteristik yang berbeda dengan industri lain misalnya industri manufaktur ataupun perbankan. Ranah industri yang berbeda memiliki karakteristik pekerjaan yang tidak sama pula dengan industri yang bergerak pada bidang lain. Industri pertelevisian mengandalkan sumber daya manusia sebagai faktor penghasil kreatifitas dan ide atau gagasan untuk dapat menghasilkan konten- 
konten produksi yang berkualitas. Pada sisi lain, industri pertelevisian juga dituntut agar dapat menjalankan manajemen untuk dapat mengelola sumber daya manusia yang dimiliki dengan baik. Hal ini diperlukan agar dapat menarik dan mempertahankan karyawan yang akan berpengaruh pada kinerja organisasi yang optimal.

Sementara itu, karyawan memiliki peran yang penting dalam organisasi sebagai pelaku dan penggerak kinerja organisasi. Kinerja organisasi akan semakin baik jika ditunjang dengan karyawan yang berkualitas dan memiliki kinerja yang baik. Pada sisi lain, era globalisasi saat ini memudahkan karyawan mendapatkan akses informasi termasuk tawaran pekerjaan di perusahaan lain. Menurut survei Badan Pusat Statistik tahun 2015, karyawan berusia muda yang tinggal di perkotaan mendapatkan informasi sebesar 90.53\% melalui telepon pintar (smartphone). Kondisi tersebut membuat karyawan yang memiliki kapasitas dan talenta akan semakin mudah mendapatkan informasi termasuk informasi kesempatan bekerja di perusahaan lain. Dampak yang dapat terjadi adalah karyawan akan semakin mudah meninggalkan pekerjaannya atau memilih untuk tetap bekerja karena memiliki keterikatan dengan perusahaan. Hal ini tidak terkecuali terjadi pada perusahaan pertelevisian. Berdasarkan studi pendahuluan yang dilakukan melalui wawancara bahwa fenomena karyawan meninggalkan pekerjaan atau berganti ke perusahaan pertelevisian lain kerap terjadi. Kondisi ini juga pernah terjadi pada salah satu TV swasta nasional dengan adanya perpindahan ratusan pegawai ke perusahaan pertelevisian lain (Pratomo, 2013). Berdasarkan hal di atas, keterikatan karyawan penting untuk diteliti dan dibahas untuk dapat mendukung peningkatan produktivitas.
Keterikatan karyawan kepada perusahaan disebut sebagai employee engagement. Federman (2009) menyatakan bahwa employee engagement (EE) merupakan derajat komitmen karyawan kepada perusahaan dan dampak dari komitmen adalah bagaimana mereka memiliki kinerja dan memperpanjang masa kerjanya. Sedangkan Hewitt (2010) menyatakan bahwa EE mencakup energi dan gairah yang ditampilkan oleh karyawan ketika bekerja berdasarkan peran dan statusnya. Dimensi dari keterikatan karyawan menurut Hewitt (2010) terdiri atas 3 dimensi yaitu: (1) Say yang diartikan sebagai karyawan mengatakan hal-hal yang positif terkait perusahaan. Keinginan karyawan untuk menunjukkan kebanggaan terhadap perusahaan dengan mengatakan kepada orang lain; (2) Stay yaitu karyawan memiliki keinginan untuk tetap bekerja di perusahaan pada jangka waktu yang lama. Keinginan karyawan untuk tetap menjadi bagian dari perusahaan; dan (3) Strive yaitu karyawan memiliki motivasi untuk memberikan usaha terbaik dalam membantu kesuksesan perusahaan. Keinginan karyawan untuk memberikan usaha terbaik dalam melakukan pekerjaan untuk meningkatkan produktivitas perusahaan.

Keterikatan karyawan dapat memberikan dampak positif kepada perusahaan antara lain retensi karyawan, tingkat kehadiran, dan juga produktifitas karyawan (Hewitt, 2010). Hal yang hampir sama disampaikan oleh Sack (2006) serta Bakker dan Demerouti (2008) yang menyatakan bahwa terdapat beberapa dampak dari EE diantaranya adalah kepuasan kerja, komitmen organisasi, dan keinginan untuk berhenti bekerja (intension to quit) yang rendah. Perusahaan yang memiliki karyawan dengan EE yang tinggi dapat menjadi sebab 
tingkat turnover yang rendah. Perusahaan yang memiliki karyawan dengan EE yang tinggi juga lebih menggambarkan kondisi karyawan yang akan tetap bekerja di perusahaan. Maslach, Schaufeli, dan Leiter (2001) menyatakan bahwa karyawan yang memiliki keterikatan kepada organisasi akan mempengaruhi bagaimana karyawan bekerja sehingga keterikatan yang rendah akan menghasilkan kinerja yang rendah pula. Begitu pula sebaliknya, peningkatkan nilai keterikatan akan meningkatkan kinerja pegawai bagi perusahaan. Pada laporan terbarunya, Hewitt (2017) menyatakan bahwa EE memberikan dampak retensi talen, tingkat kehadiran, produktivitas, serta keuntungan secara finansial dan pertumbuhan penjualan.

Keterikatan karyawan juga memiliki dampak yang positif terhadap karyawan itu sendiri berupa kondisi emosi positif dan kesehatan yang baik. Schaufeli, Bakker, dan Rhenen (2009) menyatakan bahwa karyawan yang memiliki keterikatan lebih sering mengalami emosi positif yang menjadi alasan karyawan bekerja lebih produktif. Hal ini didukung oleh penelitian Schaufeli dan Bakker (2004) pada organisasi jasa di Belanda bahwa karyawan yang memiliki keterikatan yang tinggi lebih jarang mengalami keluhan fisik misalnya sakit kepala, masalah kardiovaskuler, dan masalah perut. Hal ini juga didukung oleh Langelaan dkk. menemukan bahwa keterikatan berhubungan dengan indikator fisik termasuk hormon stres yaitu kortisol (dalam Bakker \& Demerouti, 2008). Coors juga menyatakan bahwa karyawan yang memiliki keterikatan memiliki lima (5) kali tingkat kecelakaan kerja yang lebih rendah dibandingkan karyawan yang tidak memiliki keterikatan. Apabila kecelakaan terjadi, karyawan yang memiliki keterikatan mendapatkan kecelakaan kerja yang lebih tidak serius dan tingkat kerugian yang lebih sedikit (dalam Robbins \& Judge, 2017).

Keterikatan karyawan (employee engagement) dapat dipengaruhi oleh beberapa faktor. Schaufeli (2017) menyatakan dalam Job Demand Resources/JD-R Model bahwa yang dapat mempengaruhi keterikatan diantaranya dapat berasal dari sumber pekerjaan (job resources) dan sumber personal (personal resources). Sumber pekerjaan dapat berupa sistem yang terdapat di perusahaan misalnya sistem penghargaan, kondisi linkungan kerja, keadilan dalam organisasi maupun kepemimpinan. Aspek tersebut tergambarkan sebagai persepsi dukungan organisasi (perceived organizational support/POS) yang diterima oleh karyawan. Rhoades dan Eisenberger (2002) mendefinisikan POS sebagai persepsi karyawan mengenai sejauh mana organisasi menghargai kontribusi, peduli dan memperhatikan kesejahteraan mereka, persepsi mengenai timbal balik yang disesuaikan dengan kinerja dan pemenuhan terhadap kebutuhan emosional. Rhoades dan Eisenberger (2002) menyatakan bahwa faktor pendukung POS terdiri atas 3 dimensi, yaitu (1) persepsi dukungan atasan (supervisor support) yaitu persepsi karyawan tentang sejauhmana atasan peduli dan menghargai kontribusi serta memperhatikan kesejahteraannya; (2) keadilan (fairness) yaitu persepsi individu mengenai keadilan dan keterbukaan perusahaan dalam memberikan/mentransfer sumber daya atau informasi kepada semua pegawai; dan (3) penghargaan dan kondisi kerja (rewards and organizational conditions) yaitu persepsi terkait kompensasi atau penghargaan yang diberikan kepeda karyawan serta kondisi lingkungan kerja yang saling mendukung (Eisenberger dkk., 2002). Hewitt (2017) juga 
menyatakan bahwa penghargaan juga merupakan salah satu faktor pendukung dari keterikatan karyawan. Beberapa penelitian lain juga menyebutkan bahwa POS dapat mempengaruhi keterikatan karyawan. Misalnya Dai dan Qin (2016) yang menyatakan bahwa persepsi dukungan organisasi memiliki hubungan dengan keterikatan karyawan. Hal yang serupa juga dikemukakan oleh Eisenberger, Malome dan Presson (2016) bahwa persepsi dukungan organisasi memiliki hubungan dengan penurunan ketidakhadiran dan karyawan keluar dari pekerjaan (turnover) sehingga dapat dikatakan bawa persepsi dukungan organisasi akan meningkatkan keterikatan karyawan karyawan. Gillet dkk. (2012) juga menyatakan bahwa persepsi dukungan organisasi memiliki pengaruh terhadap keterikatan kerja (work engagement) polisi.

Selain itu, sumber personal (personal resources) juga memiliki peran dalam keterikatan karyawan misalnya rasa berdaya psikologis. Spreitzer (1995) menyatakan bahwa rasa berdaya psikologis sebagai konstruk motivasi yang tercermin dalam empat area kognisi yaitu kebermaknaan (meaning), kompetensi (competence), determinasi diri (self determination) dan juga dampak (impact). Kebermaknaan (meaning) merupakan kesesuaian antara nilai atau tujuan kerja dengan misi atau harapan individu. Kompetensi (competence) didefinisikan sebagai keyakinan diri (self efficacy) yang menggambarkan keyakinan seseorang atas kemampuannya dalam melakukan aktifitas tugas menggunakan keterampilan dan pengetahuan yang dimiliki untuk mencapai keberhasilan. Determinasi diri (self determination) merupakan persepsi individu atas kekuasaan diri/otonomi dalam memulai dan melanjutkan perilaku atau proses kerja.
Pengaruh (impact) yang diartikan sebagai keyakinan seseorang bahwa pekerjaan yang dilakukan memiliki pengaruh terhadap pencapaian tujuan organisasi dan kepercayaan bahwa ia dapat mempengaruhi keluaran strategik lingkungan kerjanya (Spreitzer, 1995). Beberapa penelitian terdahulu juga menyebutkan bahwa rasa berdaya psikologis memiliki pengaruh terhadap keterikatan karyawan (Stander \& Rothmann, 2010; Bhatnagar, 2012; Wang \& Liu 2013; Abdulrab dkk., 2017). Selain itu Nawrin (2016) juga menyebutkan bahwa rasa berdaya psikologis memiliki pengaruh terhadap keterikatan kerja (work engagement) dan keterikatan organisasi (organizational engagement). Hal ini juga didukung dengan model keterikatan karyawan yang dikemukakan oleh Hewitt (2017) yang menyebutkan bahwa rasa berdaya (empowerment) merupakan salah satu faktor yang dapat mendukung keterikatan karyawan.

Penelitian mengenai kedua variabel yaitu persepsi dukungan organisasi dan rasa berdaya psikologis terhadap keterikatan karyawan terlihat masih terbatas. Sejauh ini, peneliti menemukan penelitian dari Krishnaveni dan Monica (2015) yang dilakukan di India untuk penelitian pengaruh kedua variabel terhadap keterikatan karyawan. Penelitian lain yang menggunakan rasa berdaya psikologis sebagai variabel mediasi persepsi dukungan organisasi ke keterikatan karyawan dilakukan oleh Jose dan Mampilly (2015). Hasil penelitian tersebut menunjukkan bahwa rasa berdaya psikologis memiliki peran mediasi secara penuh pada persepsi dukungan atasan terhadap keterikatan karyawan. Berdasarkan uraian di atas, model, atau hipotesis penelitian ini adalah rasa berdaya psikologi memiliki peran sebagai mediasi pengaruh persepsi dukungan organisasi pada keterikatan karyawan. Hipotesis tersebut dapat 
digambarkan sebagai berikut:

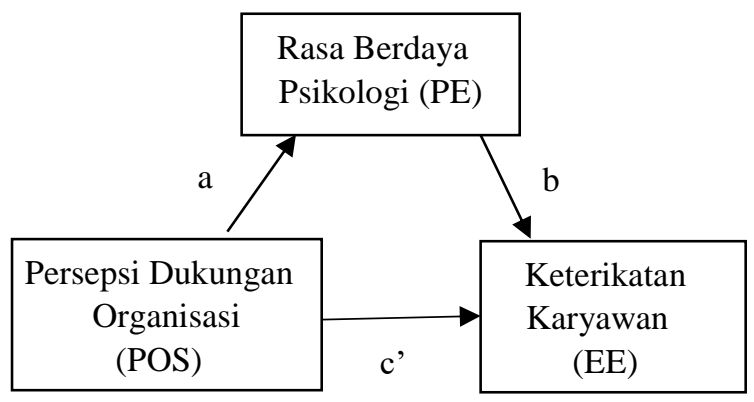

Bagan 1. Model penelitian

\section{Metode}

\section{Desain penelitian}

Merupakan penelitian kuantitatif dengan melakukan satu kali pengambilan data. Teknik sampling yang digunakan dalam penelitian ini adalah non-randomized sampling dengan teknik convenience sampling yaitu sampel diperoleh berdasarkan kesediaan individu pada saat pengambilan data dilakukan atau berdasarkan kemudahan dari sisi peneliti (Gravetter \& Forzano, 2009).

\section{Partisipan}

Partisipan terdiri dari karyawan 7 (tujuh) perusahaan pertelevisian swasta yang menjangkau area nasional dan memiliki kantor pusat di Jakarta, Indonesia. Karakteristik partisipan adalah karyawan yang telah bekerja minimal 2 (dua) tahun dan memiliki status sebagai karyawan tetap di perusahaan dengan jenjang pendidikan minimal Sekolah Menengah Atas (SMA) atau sederajat. Karyawan yang telah memiliki masa kerja minimal 2 (dua) tahun diharapkan lebih mengenali organisasi/perusahaan tempatnya bekerja dan telah memiliki pengalaman menjalankan tugas dan tanggung jawabnya ketika bekerja.

\section{Instrumen penelitian}

Persepsi dukungan organisasi (POS)

Pengukuran POS menggunakan 15 item yang merupakan adaptasi dan modifikasi dari Short POS (Eisenberger dkk., 1986). Menggunakan skala Likert dengan pilihan 1 untuk sangat tidak setuju dan 6 untuk jawaban sangat setuju. Adaptasi kuesioner dilakukan dengan melakukan alih bahasa ke dalam bahasa Indonesia. Peneliti kemudian menambahkan item peryataan sehingga setiap dimensi memiliki jumlah item yang sama pada persepsi dukungan atasan, keadilan, serta penghargaan dan kondisi kerja. Langkah berikutnya peneliti melakukan expert judgment, uji keterbacaan, dan uji coba. Hasil uji coba tersebut mendapatkan nilai realiabilitas dengan rentang 0.70 sampai 0.92 . Kaplan dan Saccuzzo (2008) menyebutkan bahwa kuesioner memiliki nilai reliabilitas yang cukup baik memiliki rentang nilai alpha Cronbach sebesar 0.7 sampai 0.8. Berikut hasil realibilitas dan kategori nilai reliabilitas menurut Guilford (1956) pada alat ukur POS. Nilai alpha Cronbach untuk alat ukur keseluruhan sebesar 0.92 masuk pada kategori sangat tinggi. Hasil reliabilitas pada saat pengambilan data diperoleh hasil 0.88 (kategori sangat tinggi) dengan rincian 0.78 (kategori tinggi) pada dimensi dukungan atasan, 0.70 (kategori tinggi) untuk dimensi penghargaan dan kondisi kerja dan juga 0.84 (kategori tinggi) untuk dimensi keadilan.

Rasa berdaya psikologis (PE)

Menggunakan adaptasi dan modifikasi kuesioner dari Speitzer (1995) yang dilakukan oleh Mangundjaya (2016) dengan jumlah 16 item. Alat ukur menggunakan skala Likert dengan nilai 1 sampai 6. Skor 1 berarti sangat tidak setuju dan 6 berarti sangat setuju. Berikut kategori nilai reliabilitas menurut Guilford (1956) pada alat ukur PE. Nilai alpha Cronbach sebesar 0.90 yang masuk pada kategori sangat tinggi. Pada waktu dilakukan 
pengujian kembali pada penelitian ini terlihat bahwa hasil reliabialitas diperoleh 0.87 (kategori sangat tinggi). Lebih lanjut, nilai alpha Cronbach per dimensi yaitu 0.79 (kategori tinggi) untuk dimensi kebermaknaan (meaning), 0.79 (kategori tinggi) untuk dimensi kompetensi (competence), 0.75 (kategori tinggi) untuk dimensi determinasi diri (self determination) dan juga 0.86 (kategori sangat tinggi) untuk dimensi pengaruh (impact).

\section{Keterikatan karyawan (Employee engagement/EE)}

Pengukuran menggunakan adaptasi alat ukur keterikatan karyawan yang dikembangkan oleh Hewitt (2015) yang berjumlah 15 item dengan 5 item setiap dimensi. Alat ukur menggunakan skala Likert dengan skala 1 sampai 6 . Skor 1 berarti sangat tidak setuju dan 6 berarti sangat setuju. Setiap tahapan proses adaptasi alat ukur EE sama dengan tahapan dalam proses adaptasi POS. Berikut kategori nilai reliabilitas menurut Guilford (1956) pada alat ukur EE. Nilai alpha Cronbach sebesar 0.92 (kategori sangat tinggi). Lebih rinci, nilai alpha Cronbach per dimensi pada saat pengambilan data yaitu 0.83 (kategori sangat tinggi) untuk dimensi Say, 0.81 (kategori sangat tinggi) untuk dimensi Stay, dan juga 0.80 (kategori sangat tinggi) untuk dimensi Strive. Sedangkan reliabilitas keseluruhan diperoleh hasil 0.89 (kategori sangat tinggi).

\section{Pengambilan data dan teknis analisis data}

Pengambilan data dalam penelitian ini menggunakan kuesioner yang diberikan secara langsung kepada partisipan oleh peneliti atau pihak pengelola sumber daya manusia perusahaan. Sebelum mengisi kuesioner partisipan membaca atau dijelaskan tujuan penelitian serta menandatangani informed concern penelitian. Pengolahan data penelitian ini menggunakan statistik deskriptif SPSS 22 yaitu independent T-test dan Manova, sedangkan pengolahan variabel mediasi menggunakan Process Hayes V3.

\section{Hasil}

Dari hasil pengambilan data yang dilakukan melalui kuesioner hardcopy yang diberikan langsung kepada responden atau ke pengelola sumber daya manusia pada karyawan beberapa industri pertelevisian swasta nasional yang berdomisili di Jakarta, Indonesia, didapatkan hasil pengolahan data deskriptif sebagaimana dapat dilihat selengkapnya pada Tabel 1 .

Mayoritas partisipan berjenis kelamin laki laki (64\%) dan 36\% adalah perempuan. Jika dilihat dari masa kerja menurut Tulus (1992) diketahui bahwa $45 \%$ partisipan tergolong memiliki masa kerja baru 2-5 tahun, $32 \%$ memiliki masa kerja sedang dan 32\% memiliki masa kerja lama yaitu lebih dari 10 tahun. Pada industri pertelevisian terlihat bahwa mayoritas karyawan memiliki jenjang pendidikan strata 1 yaitu sebesar $84 \%$. Sedangkan berdasarkan usia perkembangan karir Donald Super (dalam Santrock, 2012), hanya $2 \%$ karyawan yang masih masuk pada tahap eksplorasi terhadap pekerjaan, yaitu karyawan memikirkan berbagai alternatif karir dan belum mengambil keputusan yang mengikat. Sedangkan sebesar $13 \%$ sudah berada pada tahap pemeliharaan yaitu mempertahankan karir atau pekerjaan yang saat ini dijalankan. Mayoritas partisipan penelitian $(85 \%)$ berada pada tahap pemantapan/ pendirian karir, yaitu tahap individu telah memiliki bidang pekerjaan yang sesuai dan berusaha memantapkan pekerjaannya secara permanen pada bidang yang dipilihnya saat ini. 
Tabel 1.

Deskriptif partisipan, mean dan standar deviasi

\begin{tabular}{|c|c|c|c|c|c|c|c|c|c|c|c|}
\hline \multirow[b]{2}{*}{ Kriteria } & \multirow[b]{2}{*}{ Jumlah } & \multirow[b]{2}{*}{$\%$} & \multicolumn{3}{|c|}{$\mathrm{PE}$} & \multicolumn{3}{|c|}{$\mathrm{EE}$} & \multicolumn{3}{|c|}{ POS } \\
\hline & & & M & SD & Sig & M & SD & Sig & M & SD & Sig \\
\hline \multicolumn{12}{|l|}{ Jenis kelamin } \\
\hline Laki-laki & 74 & $64 \%$ & 4.96 & 0.49 & & 4.53 & 0.55 & & 4.18 & 0.62 & \\
\hline Perempuan & 42 & $36 \%$ & 4.79 & 0.49 & 0.69 & 4.19 & 0.68 & 0.07 & 3.93 & 0.62 & 0.42 \\
\hline \multicolumn{12}{|l|}{ Usia } \\
\hline 15- 24 tahun & 2 & $2 \%$ & 4.97 & 0.66 & & 4.43 & 0.98 & & 3.93 & 0.28 & \\
\hline 25-44 tahun & 99 & $85 \%$ & 4.90 & 0.46 & & 4.35 & 0.61 & & 4.05 & 0.64 & \\
\hline$>45$ tahun & 15 & $13 \%$ & 4.49 & 0.67 & 0.94 & 4.76 & 0.55 & 0.34 & 4.38 & 0.57 & 0.13 \\
\hline \multicolumn{12}{|l|}{ Pendidikan } \\
\hline SMA & 2 & $2 \%$ & 3.94 & 0.27 & & 4.70 & 0.14 & & 4.46 & 0.47 & \\
\hline Diploma 3 & 10 & $9 \%$ & 4.99 & 0.60 & & 4.82 & 0.60 & & 4.47 & 0.41 & \\
\hline Strata 1 & 97 & $84 \%$ & 4.90 & 0.48 & & 4.34 & 0.62 & & 4.04 & 0.65 & \\
\hline Strata 2 & 7 & $6 \%$ & 5.05 & 0.30 & $0.03 * *$ & 4.66 & 0.34 & 0.06 & 4.12 & 0.56 & 0.18 \\
\hline \multicolumn{12}{|l|}{ Jabatan } \\
\hline Staf & 48 & $41 \%$ & 4.47 & 0.53 & & 4.17 & 0.64 & & 3.86 & 0.66 & \\
\hline Supervisor & 42 & $36 \%$ & 4.97 & 0.44 & & 4.47 & 0.54 & & 4.14 & 0.55 & \\
\hline Manajer & 26 & $22 \%$ & 5.08 & 0.42 & $0.01 *$ & 4.74 & 0.52 & $0.00 *$ & 4.43 & 0.53 & $0.01 *$ \\
\hline \multicolumn{12}{|l|}{ Masa Kerja } \\
\hline $2-5$ tahun & 52 & $45 \%$ & 4.77 & 0.50 & & 4.23 & 0.65 & & 3.96 & 0.65 & \\
\hline 6-10 tahun & 32 & $28 \%$ & 5.05 & 0.47 & & 4.52 & 0.60 & & 4.24 & 0.68 & \\
\hline$>10$ tahun & 32 & $28 \%$ & 4.97 & 0.46 & $0.02 * *$ & 4.59 & 0.49 & $0.01 *$ & 4.15 & 0.52 & 0.10 \\
\hline
\end{tabular}

*korelasi signifikan pada level 0.01 ( p < 0.01), **korelasi signifikan pada level 0.05 (p < 0.05$)$

Kuesioner menggunakan skala Likert yang memiliki rentang skor 1 berarti sangat tidak setuju dan 6 berarti sangat setuju. Berdasarkan pengolahan data diatas didapatkan gambaran bahwa, partisipan memberikan penilaian yang lebih rendah terhadap variabel sumber pekerjaan yaitu POS yang mencakup persepsi dukungan yang diterima karyawan dari atasan, keadilan yang diterima ketika bekerja dan juga terkait kompensasi dan penghargaan yang diterima. Sedangkan variabel personal berupa rasa berdaya psikologis memiliki nilai yang lebih tinggi. Hal ini dapat disebabkan bahwa pengambilan data dilakukan dengan metode penilaian diri (self report), karyawan memiliki cenderung untuk menilai diri sendiri lebih baik dibandingkan menilai faktor eksternal yaitu
POS. Diketahui juga, berdasarkan data deskriptif bahwa jenjang pendidikan yang semakin tinggi membuat karyawan memiliki nilai PE yang lebih tinggi. Nilai PE yang lebih tinggi juga diketahui pada karyawan yang memiliki masa kerja sedang yaitu 6-10 tahun. Masa kerja juga membuat karyawan memiliki nilai EE yang semakin tinggi. Selain itu juga didapatkan gambaran bahwa semakin tinggi jenjang jabatan karyawan di perusahaan memiliki nilai pada semua variabel PE, EE dan POS yang semakin tinggi pula.

Berdasarkan Tabel 2 diketahui bahwa hubungan POS ke EE memiliki korelasi positif sebesar $(r=0.614)$. Sedangkan hubungan POS ke PE memiliki nilai korelasi positif ( $\mathrm{r}=0.374)$ dan hubungan $P E$ ke EE memiliki nilai 
korelasi positif sebesar $(\mathrm{r}=0.502)$. POS memiliki korelasi positif kepada kedua variable yaitu ke EE dan PE. Sedangkan PE juga memiliki korelasi dengan EE. Semua hubungan korelasi memiliki signifikansi pada taraf dibawah $0.01 \quad(\mathrm{p}<0.01)$. Selanjutnya, pengolahan data dilakukan dengan memasukkan PE sebagai variabel mediasi antara POS dan EE yang dapat dilihat pada Tabel 3.

Tabel 2.

Korelasi antar variabel EE, PE dan POS

\begin{tabular}{llcc}
\hline Variabel & EE & PE & POS \\
\hline EE & 1,000 & $0,502^{*}$ & $0,614^{*}$ \\
PE & $0,502^{*}$ & 1,000 & $0,74^{*}$ \\
POS & $0,614^{*}$ & $0,374^{*}$ & 1,000 \\
\hline
\end{tabular}

*signifikan pada level 0,01 (p<0,01) (one-tailed)

Berdasarkan Tabel 3 di atas diketahui bahwa nilai $\mathrm{a}=0.312, \mathrm{~b}=0.370$ dan $\mathrm{c}^{\prime}=0.483$. Model regresi yang terbentuk adalah:

$$
\begin{aligned}
& M=59.286+0.312 X \\
& Y=7.414+0.483 X+0.370 M
\end{aligned}
$$

Diketahui juga bahwa nilai efek tidak langsung yaitu dengan mengalikan efek POS ke PE dengan PE ke EE yaitu $a b=0.312(0.370)$ $=0.115$ dengan nilai hubungan positif dan tingkat kepercayaan $95 \%$ dan memiliki nilai interval di atas nol (BootLLCI 0.05 dan BootULCI 0.203).

Tabel 3.

Hasil pengolahan data pengujian hipotesis
Efek langsung POS ke PE memiliki nilai $c^{\prime}=0.483$ dengan nilai $\mathrm{LLCI}=0.339$, nilai ULCI $=0.627$ dan tingkat kepercayaan $95 \%$. Total efek POS ke EE selain dapat dilihat pada tabel juga dapat diketahui dengan melakukan fungsi penambahan $\mathrm{c}=\mathrm{c}$ ' $+\mathrm{ab}$ $=0.483+0.115=0.599 \quad$ dengan nilai LLCI $=0.456$, nilai ULCI $=0.742$ dan tingkat kepercayaan 95\% yang dapat dilihat di Tabel 3. Semua hubungan bernilai positif, hal ini menunjukkan bahwa peningkatan POS dan PE akan meningkatkan EE. Hasil pengolahan data juga menyebutkan bahwa POS memiliki pengaruh ke EE dan PE memiliki pengaruh ke EE. Selain itu juga dapat diartikan bahwa PE memiliki pengaruh mediasi parsial positif antara POS ke EE. Peningkatan terhadap PE karyawan akan semakin meningkatkan EE.

\section{Diskusi}

Berdasarkan pengolahan data didapatkan hasil sesuai dengan hipotesis penelitian. Hasil penelitian menunjukkan bahwa PE memiliki peran mediasi parsial yang positif terhadap hubungan POS dengan EE pada pegawai industri pertelevisian di Jakarta, Indonesia. Hasil ini menunjukkan bahwa untuk meningkatkan EE pegawai, selain meningkatkan POS, juga dapat meningkatkan PE pegawai. Peningkatan kedua variabel akan meningkatkan EE secara positif. Hasil ini menunjukkan bahwa POS sebagai sumber pekerjaan (job resources) memiliki pengaruh positif terhadap EE. Dengan kata lain, karyawan yang mempersepsikan mendapatkan dukungan dari perusahaan akan meningkatkan EE (Dai \& Qin, 2016; Eisenberger, Malome, \&

\footnotetext{
*signifikan pada level 0.01 ( $\mathrm{p}<0.01)$
}

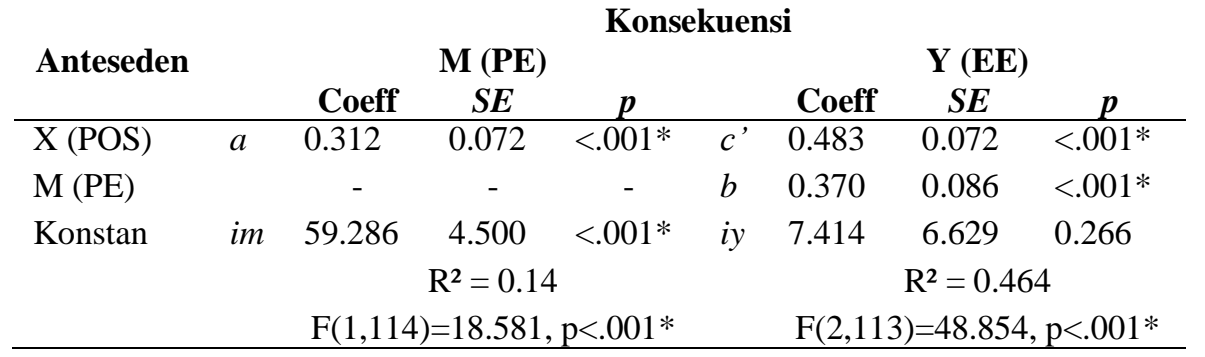

Presson, 2016). Hal ini juga sejalan dengan model keterikatan pegawai dari Sack (2006) 
yang menyebutkan bahwa POS merupakan anteseden dari EE. Karyawan yang mempersepsikan bahwa mereka mendapatkan atasan yang mendukung, peduli dan menghargai kontribusi serta memperhatikan kesejahteraannya akan memiliki EE yang lebih tinggi (Eisenberger dkk., 2002).

Rasa berdaya psikologis sebagai sumber personal (personal resources) juga memiliki pengaruh kepada EE. Karyawan yang memiliki PE akan memiliki EE terhadap perusahaan (Stander \& Rothmann, 2010; Bhatnagar, 2012; Wang \& Liu 2013; Abdulrab dkk., 2017). Karyawan yang meyakini bahwa misi atau tujuan organisasi sejalan dengan nilai/tujuan yang diyakini akan meningkatkan keterikatan. Karyawan yang memiliki kompetensi, memiliki keyakinan diri tinggi dan akan secara terus menerus menantang diri sendiri dalam menciptakan target dan tujuan yang lebih tinggi dengan memilih level pekerjaan yang lebih sulit (Luthans, 2008). Rasa berdaya psikologis juga menggambarkan bahwa karyawan memiliki otonomi dalam memulai dan melanjutkan perilaku atau proses kerja (Spreitzer, 1995). Seseorang yang memiliki otonomi dalam bekerja tercermin dalam pengambilan keputusan yang berkaitan dengan metode kerja, prosedur, waktu, dan juga usaha yang dilakukan (Spreitzer, 1995). Rasa berdaya psikologis juga membuat karyawan meyakini bahwa pekerjaan yang ia lakukan memiliki pengaruh terhadap tujuan organisasi. Seseorang yang meyakini bahwa pekerjaan yang dilakukan berdampak pada pekerjaan orang lain akan lebih efektif dalam bekerja (Spreitzer, 1995). Dapat disimpulkan bahwa, sumber personal berupa rasa berdaya psikologis memiliki pengaruh terhadap EE.

Hasil lainnya menunjukkan bahwa PE memiliki peran mediasi parsial pengaruh POS terhadap EE. Hal ini berbeda dengan penelitian yang dilakukan oleh Jose dan Mampilly (2015) yang menunjukkan bahwa PE berperan sebagai mediasi penuh pengaruh POS ke EE. Kondisi ini dapat disebabkan perbedaan karakteristik partisipan. Pada penelitian sebelumnya keseluruhan partisipan merupakan karyawan non manajerial yang berkerja pada organisasi penyedia jasa (kesehatan, asuransi, dan telekomunikasi). Sedangkan pada penelitian ini merupakan perusahaan industri pertelevisian dengan $58 \%$ partisipan merupakan karyawan yang sudah berada pada posisi manajerial dan selebihnya adalah karyawan non manajerial. Pada penelitian ini komposisi partisipan yang non manajerial dan manajerial memiliki persentase yang hampir sama.

Pada pengolahan data deskriptif menunjukkan bahwa modal individu (human capital) seperti tingkat pendidikan, jabatan dan masa kerja berpengaruh signifikan terhadap PE. Karyawan dengan tingkat pendidikan jabatan yang lebih tinggi dan masa kerja yang lebih lama akan semakin memiliki PE. Modal individu dapat digunakan ketika bekerja dalam dimensi determinasi diri (self determination), pengaruh (impact) maupun merasa kompeten (competence) untuk melakukan pekerjaan. Hal ini disebabkan karyawan yang memiliki modal individu berupa level pengetahuan, ketrampilan dan pengalaman dapat menggunakan modal tersebut dalam memudahkan penyelesaian pekerjaan. Selain itu, karyawan yang memiliki modal individu yang tinggi memiliki hubungan dengan kemampuan mengambil tindakan dan memiliki pengaruh ditempat kerja (Seibert dkk., 2011). Hal ini juga didukung peneliti (Koesindratmono \& Septarini, 2011; Dickson \& Lorenz, 2009) yang menyebutkan masa kerja memiliki hubungan dengan PE 
karyawan. Selain itu, hasil penelitian Rashkovits dan Livne (2013) juga menunjukkan bahwa tingkat pendidikan memiliki pengaruh terhadap PE.

Hasil yang didapatkan dari pengolahan data deskriptif lainnya, yaitu jabatan dan masa kerja karyawan memiliki hubungan dengan EE. Semakin tinggi jabatan dan semakin lama karyawan bekerja, karyawan akan memiliki EE yang semakin tinggi terhadap perusahaan. Jabatan yang semakin tinggi memberikan tanggungjawab yang semakin kompleks dan berdampak terhadap kinerja organisasi. Hal ini sejalan dengan Hewitt (2015) yang menyebutkan bahwa karakteristik pekerjaan merupakan anteseden dari EE. Hasil lainnya menunjukkan bahwa karyawan yang memiliki masa kerja yang lebih lama memiliki EE yang lebih tinggi. Hal ini disebabkan karyawan yang telah memiliki masa kerja yang lebih lama telah beradaptasi dengan tugas dan lingkungan pekerjaan sehingga membuat karyawan merasa nyaman serta tidak keluar dari pekerjaanya (Kreitner \& Kinicki, 2004). Hal ini didukung hasil penelitian Kim dkk. (2017) bahwa tingkat jabatan memiliki hubungan negatif dengan burnout yang merupakan kebalikan dari keterikatan (Roma dkk., 2002) dan hasil penelitian Kurniawati (2014) bahwa masa kerja memiliki hubungan dengan keterikatan kerja karyawan. Tingkat jabatan juga berhubungan dengan POS. Semakin tinggi tingkat jabatan, karyawan akan semakin mendapatkan dukungan dari perusahaan misalnya dalam hal pendapatan serta tunjangan yang diterima karyawan. Hasil penelitian dapat digunakan sebagai masukan oleh perusahaan dengan membuat perancangan program yang dapat meningkatkan peran dari dukungan organisasi (POS) maupun peningkatkan rasa berdaya psikologis (PE) karyawan agar keterikatan karyawan (EE) meningkat.

Pengembangan yang dapat dilakukan untuk meningkatkan PE adalah meningkatkan pusat penilaian diri (core self evaluation/CSE). Penilaian diri positif merupakan anteseden dari pemberdayaan psikologis (Seibert dkk., 2011). Hal ini disebabkan penilaian diri positif merupakan penilaian dasar yang membuat seseorang merasa berharga, kompeten dan memiliki kemampuan untuk berhubungan dengan lingkungan. Pusat penilaian diri terdiri atas pusat kendali (locus of control), harga diri (self esteem), keyakinan diri umum (generalized self-efficacy) dan stabilitas emosi (Judge, 1997). Selain itu, hal lain yang dapat dikembangkan untuk meningkatkan PE adalah peningkatan modal individu (human capital). Pengembangan pusat penilaian diri dan juga modal individu dapat dilakukan dengan coaching, mentoring, job enrichment, pelatihan kompetensi menajerial maupun teknis, menumbuhkan budaya pembelajaran mandiri (self learning) serta dukungan untuk melanjutkan jenjang pendidikan yang lebih tinggi. Selain itu, saran untuk meningkatkan POS dapat dilakukan dengan meningkatkan dukungan atasan kepada bawahan, menerapkan kebijakan manajemen perusahaan yang adil dan objektif, melakukan kajian pemberian kompensasi, dan penghargaan secara proporsional serta meningkatkan perspektif bahwa karyawan merupakan aset penting bagi perusahaan untuk dapat menghasilkan ide dan konten produksi yang berkualitas.

Sementara itu, terdapat beberapa keterbatasan dalam penelitian. Pengambilan data menggunakan kuesioner dalam bentuk penilaian diri (self report). Hal ini dapat disebabkan terjadi social desirability yang dapat menimbulkan bias dalam menjawab 
pernyataan yang diberikan. Partisipan dapat memberikan jawaban yang lebih diterima oleh masyarakat dan menguntungkan diri sendiri dengan cenderung menunjukkan hal baik pada penilaian diri sendiri (Jaya dkk., 2011). Agar dapat meminimalisir hal tersebut, pada penelitian selanjutkan pengambilan data dapat dikombinasikan dengan metode penelitian lain misalnya wawancara. Kombinasi dengan metode wawancara juga dapat menggali lebih dalam terkait setiap dimensi dari persepsi dukungan organisasi, misalnya bentuk dukungan atasan yang dibutuhkan, jenis kompensasi dan penghargaan yang dipersepsikan oleh karyawan. Sedangkan untuk dapat menggali keadilan (fairness) yang dipersepsikan karyawan dapat dilakukan dengan menggunakan keadilan prosedural dan keadilan distributif yang merupakan anteseden dari EE (Sack, 2006) untuk memperdalam hasil penelitian.

Saran yang dapat memperkaya pengolahan data lainnya, misalnya dengan melakukan hal-hal sebagai berikut. Melakukan klasifikasi partisipan berdasarkan departemen, karena setiap departemen memiliki karakteristik pekerjaan yang berbeda, misalnya departemen yang bekerja mengikuti jam kerja seperti industri lainnya dan juga departemen yang bekerja dilapangan atau bekerja dengan sistem pergantian (shift). Pekerjaan yang ada pada departemen berbeda memiliki karakteristik pekerjaan yang berbeda. Karakteristik pekerjaan merupakan salah satu anteseden dari keterikatan (Sack, 2006; Kumar \& Renugadevi, 2013). Hackman dan Oldham menyebutkan bahwa karakteristik pekerjaan mencakup lima (5) karakterik utama yaitu variasi keterampilan, identifikasi tugas, signifikansi tugas, autonomi, dan juga umpan balik (dalam Cummings \& Worley, 2015). Selain itu juga belum adanya perbedaan data berdasarkan industri televisi yang berbasis FTA (free to air)/siaran bebas dan juga TV berlangganan. Strategi bisnis yang berbeda dapat menjadi sebab adanya perbedaan kondisi kerja misalnya POS yang diterima pegawai. Hal lainnya yang dapat dipertimbangkan adalah pemisahan partisipan yang berasal dari beberapa perusahaan yang berbeda. Untuk analisis lebih lanjut, dapat dilakukan penambahan sampel penelitian dan juga melakukan pengolah variabel independen dan juga mediator sampai pada level dimensi dari variabel.

\section{Daftar Pustaka}

Abdulrab, M., Zumrah, A. R., Almaamari, Q., \& Altahitah, A. (2017). The Role of Psychological Empowerment on Work Engagement: The Development of Conceptual Framework. International Journal of Business Management and Economic Research, 8(6), 1157-1163.

Badan Pusat Statistik. (2015). Statistik pemuda Indonesia: Hasil survei sosial ekonomi nasional [Indonesian Youth Statistics: National Socio-Economic Survey Results]. Diambil dari https://media.neliti.com/media/publicati ons/48324-ID-statistik-pemudaindonesia-2015.pdf.

Bakker, A. B., \& Demerouti, E. (2008). Towards a Model of Work Engagement. Career Development International, 13 (3), 209-223. doi: https://doi.org/10.1108/1362043081087 $\underline{0476}$

Bhatnagar, J. (2012). Management of innovation: role of psychological empowerment, work engagement and turnover intension in the Indian context. 
The International Journal of Human

Resouce Management, 23, 928-951. doi: https://dx.doi.org/10.1080/09585192.20 12.651313.

Cummings, T.G., \& Worley, C.G. (2015). Organizational Development and Change 10th Edition. Boston, MA: Cengage Learning.

Dai, K., \& Qin, X. (2016). Perceived Organizational Support and Employee Engagement: Based on the Research of Organizational Identification and Organizational Justice. Open Journal of Social Science, 4, 46-57. doi: https://doi.org/10.4236/jss.2016.412005

Dickson, K. E, \& Lorenz, A. (2009). Psychological Empowerment and Job Satisfaction of Temporary and Part-time Nonstandard Worker: A Preliminary Investigation. Journal of Behavioral and Applied Management, 10(2), 166-191. doi:

\section{http://dx.doi.org/10.2307/30040639.}

Eisenberger, R., Huntington, R., Hutchinson, S., \& Sowa, D. (1986). Perceived Organizational Support. Journal of Applied Psychology, 71(3), 500-507. doi: $\quad$ http://dx.doi.org/10.1037/00219010.71.3.500

Eisenberger, R., Stinglhamber, F., Vandenberghe, C., Sucharski, I. L., \& Rhoades, L. (2002). Perceived Supervisor Support: Contributions to Perceived Organizational Support and Employee Retention. Journal of Applied Psychology, 87(3), 565-573. doi: http://dx.doi.org/10.1037/00219010.87.3.565

Eisenberger, R., Malone, G. P., \& Presson, W. D. (2016). Optimizing Perceived
Organizational Support to Enhance Employee Engagement. SHRM-SIOP Science of HR Series. Diambil dari http://www.siop.org/SIOPSHRM/SHRM-SIOP POS.pdf.

Federman, B. (2009). Employee Engagement: A Road for Creating Profits, Optimizing Perfomance, and Increasing Loyalty. San Fransisco, CA: Jossey Bass.

Gillet, N., Huart, I., Colombat, P., \& Fouquereau, E. (2012). Perceived Organizational Support, Motivation, and Engagement Among Police Officer. Journal Professional Psychology; Research and Practise, 44(1), 44-55. doi:

https://dx.doi.org/10.1037/a0030066.

Gravetter, F. J., \& Forzano, L. A. (2009). Research Methods for the Behavioral Science 3rd Edition. Belmont, CA: Wadsworth.

Guilford, J. P. (1956). Fundamental Statistic in Psychology and Education 3rd Edition. New York: McGraw-Hill.

Hackman, R. J., \& Oldham, R. G. (1980). Work Redesign. Reading, MA: AddisonWesley.

Hayes, A. F. (2018). Introduction to Mediation, Moderation, and Conditional Process Analysis-A Regression-Based Approach 2nd Edition. New York: The Guilford Press.

Hewitt. (2010). Engagement 2.0: Focus on the Right People, Build the Excitement, Preserve the Passion. USA: AON Hewitt.

Hewitt. (2015). AON Hewitt's Model of Employee Engagement. USA: AON Empower Results. 
Hewitt. (2017). 2017 Trends in Global Employee Engagement. USA: AON Empower Results.

Jaya, E. S., Hartana, G. T. B., \& Mangundjaya, W. G. (2011). Menyidik Keberadaan Social Desirability (SD) pada Variabel Penelitian Perilaku. Jurnal Psikologi Indonesia, VIII(1), 54-62.

Jose, G., \& Mampilly, S. R. (2015). Relationships among Perceived Supervisor Support, Psychological Empowerment and Employee Engagement in Indian Workplace. Journal of Workplace Behavior Health, 30(3), 231-250. doi: https://doi.org/10.1080/15555240.2015. 1047498.

Kaplan, R. M., \& Saccuzzo, D. P. (2008). Psychological Testing. Boston, MA: Cengage Learning.

Kim, W. H., Kim, W. H., Ra, Y. A., Ra, Y. A., Park, J. G., Park, J. G. \& Kwon, B. (2017). Role of Burnout on Job Level, Job Satisfaction, and Task Performance. Leadership \& Organization Development Journal, 38(5), 630-645. doi: https://doi.org/10.1108/LODJ-112015-0249

Kumar, K. A., \& Renugadevi, R. (2013). Antecedent and Consequences of Employee Engagement-A Hypothetical Approach. Journal of Business and Management, 9(3), 52-57.

Koesindratmono, F., \& Septarini, B. S. (2011). Hubungan antara Masa kerja dengan Pemberdayaan Psikologis pada Karyawan PT. Perkebunan Nusantara X (Persero), INSAN, 13(1).

Kurniawati, I. D. (2014). Masa Kerja dengan
Job Engagement Pada Karyawan. Jurnal Ilmiah Psikologi Terapan, 2(2). doi: https://doi.org/10.22219/jipt.v2i2.2005

Kreitner, R., \& Kinicki, A. (2004). Organizational Behavior 5th Edition. New York: McGraw Hill.

Krishnaveni, R., \& Monica, R. (2016). A Study on Antecedents and Consequences of Engagement: A Conceptual Framework. International Journal of Social Sciences and Interdisciplinary Research, 5(7), 20-27.

Luthans, F. (2008). Organizational Behaviour 8th Edition. New York: McGraw Hill.

Nawrin, R. (2016). Impact of Psychological Empowerment on Employees' Work and Organization Engagement: A study in the Manufacturing Sectors, Bangladesh. Mediterranean Journal of Social Science, 7(5), 389-395. doi: http://dx.doi.org/10.5901/mjss.2016.v7n $\underline{5 p 389}$

Malik, F., Chungtai, S., Iqbal, Z., \& Ramzan. M. (2013). Does Psychological Empowerment Bring about Employee Commitment? Evidence from Telecommunication Sector of Pakistan. Journal of Business Studies Quaerterly, 5(1), 14-21.

Mangundjaya, W. L. (2016). Psikologi dalam Perubahan Organisasi. Jakarta: Swasthi Adi Cita.

Mangundjaya, W. L. (2016). Pengaruh Kepemimpinan Perubahan Terhadap Komitmen Afektif untuk Berubah Melalui Kepercayaan pada Organisasi dan Rasa Berdaya Psikologis, Disertasi, Universitas Indonesia.

Maslach, C., Schaufeli, W. B., \& Leiter, M. P. 
(2001). Job Burnout. Annual Review of Psychology, 52, 397-422. doi: https://doi.org/10.1146/annurev.psych.5 2.1.397

Pratomo, Y. (2013). Sekitar 200 karyawan TransTV hengkang ke perusahaan Wishnutama. Diambil dari https://www.merdeka.com/peristiwa/sek itar-200-karyawan-transtv-hengkangke-perusahaan-wishnutama.html

Roma, V. C., Schaufeli, W. B., Bakker, A. B., \& Lloret, S. (2006). Burnout and Work Engagement: Independent Factors or Opposite Poles? Journal of Vocational Behavior, 68(1), 165-174. doi: http://dx.doi.org/10.1016/j.jvb.2005.010 03.

Rashkovits, S., \& Livne, S. (2013). The Effect of Educational Level on Psychological Empowerment and Burnout-The Mediating Role of Workplace Learning Behaviors. International Journal of Psychology and Behavioral Sciences, 7(6), 1896-1901.

Robbins, S. P. (2005). Organizational Behavior 11th Edition. New Jersey: Prentice-Hall, Inc.

Robbins, S. P., \& Judge, T. A. (2017). Organizational Behavior 17th Edition. London: Pearson Education, Inc.

Rhoades, L., \& Eisenberger, R. (2002). Perceived Organizational Support: A Review of The Literature. Journal of Applied Psychology, 87, 698-714. doi: http://dx.doi.org/10.1037/00219010.71.3.500.

Sack, A. M. (2006). Antecedent and Consequences of Employee Engagement. Journal of Managerial
Psychology, 21(7), 600-619. doi: http://dx.doi.org/0.1108/026839406106 90169.

Santrock, J. W. (2012). Life-span Development 13th Edition. New York: McGraw-Hill.

Schaufeli, W. B., \& Bakker, A. B. (2004). Job Demands, Job Resource, and Their Relationship with Burnout and Engagement: A Multi-sample Study. Journal of Organizational Behavior, 25(3), 293-315. doi: https://doi.org/10.1002/job.248.

Schaufeli, W. B., Bakker, A. B., \& Van Rhenen, W. (2009). How Changes in Job Demands and Resources Predict Burnout, Work Engagement, and Sickness Absenteeism. Journal of Organizational Behavior, 30(7), 893917. doi: http://dx.doi.org/10.1002/job.595

Schaufeli, W. B. (2017). Applying the Job Demands-Resources model: A 'How to' Guide to Measuring and Tackling Work Engagement and Burnout. Organizational Dynamics, 46, 120-132, doi: http://dx.doi.org/10.1016/j.orgdyn.

Seibert, S.E., Wang, G., \& Courtright, S.H. (2011). Antecedents and Consequences of Psychological and Team Empowerment in Organizations: A Meta-analytic Review. Journal of Applied Psychology, 96(5), 981-1003. doi:

http://dx.doi.org/10.1037/a0022676.

Spreitzer, G. M. (1996). Social Structural Characteristics of Psychological Empowerment. Academy of Management Journal, 39(2), 483-504. doi: http://dx.doi.org/10.2307/256789. 
Spreitzer, G. M., Kizilos, M. A., \& Nason, S. W. (1997). A Dimensional Analysis of the Relationship Between Psychological Empowerment and Effectiveness Satisfaction and Strain. Journal of Management, 23(5), 679-704. doi: https://doi.org/10.1016/S01492063(97)90021-0

Spreitzer, G. M. (1995). Psychological Empowerment in the Workplace: Dimensions, Measurement, and Validation. Academy of Management Journal, 38(5), 1442-1465. doi: http://dx.doi.org/10.2307/256865.

Stander, M. W., \& Rothmann, S. (2010). Psychological Empowerment, Job Insecurity and Employee Engagement. SA Journal of Industrial Psychology, 36(1), 1-8. doi: https://doi.org/10.4102/sajip.v41i1.1259

Tulus, M. A. (1992). Manajemen Sumber Daya Manusia: Buku Panduan Mahasiswa. Jakarta: P.T. Gramedia Pustaka Utama.

Wang, S., \& Liu, Y. (2013). Impact of Professional Nursing Pratice Environment and Psychological Empowerment on Nurses' Work Engagement: Test of Structural Equation Modelling. Journal of Nursing Management, 23(3), 287-296. doi: https://doi.org/10.1111/jonm.12124. 